\title{
Influence of barn drying of fodder on respiratory symptoms and function in dairy farmers of the Doubs region of France
}

\author{
J C Dalphin, J C Polio, D Pernet, M F Maheu, B Toson, A Dubiez, E Monnet, \\ J J Laplante, A Depierre
}

\begin{abstract}
Background - A previous study showed there to be fewer microorganisms (especially thermophilic actinomycetes) on farms with artificial barn drying of fodder than on those using traditional storage methods. A cross sectional study was performed to see whether barn drying provides protection against respiratory problems in dairy farmers.
\end{abstract}

Methods - The respiratory symptoms and function of a group of 123 farmers with daily exposure to cattle foddering from farms which had had a barn drying system for at least three years were compared with those of a representative sample of 274 farmers working in farms with traditional storage in five districts in the Doubs region of France.

Results - Both groups were comparable for mean age, weight, height, smoking habits, alcohol consumption, past history of respiratory disease, history of allergy, geographical location of the farm, and length of exposure. Retrospectively estimated exposure to fodder was greater in the group using a barn drying system than in the group working with traditional storage. Acute symptoms at exposure (rhinitis, eye irritation, dry cough, asthma symptoms) and chronic symptoms all tended to be less frequent in the barn drying group, although not individually significantly so. Mean (SD) respiratory function parameters were higher in the barn drying group than in the traditional group: \% vital capacity (VC) 104 (14) v 102 (15); \% forced expiratory volume in one second $\left(F_{E V}\right) 99$ (14) v 94 (18); \% FEV 1 /VC 96 (11) v 92 (16); \% forced mid expiratory flow $\left(\mathrm{FEF}_{25-75}\right) 87$ (24) $v 79$ (25).

Conclusion - The results of this cross sectional study suggest that barn drying of fodder may protect respiratory function in dairy farmers.

(Thorax 1994;49:50-53)

The Mutualite

Sociale Agricole du

Doubs, Besançon,

France

J J Laplante

Reprint requests to:

Dr J C Dalphin.

Received 22 April 1993 Returned to authors 22 June 1993

Revised version received 7 October 1993

Accepted for publication

11 October 1993

Exposure to organic dust in farmers is associated with diseases such as asthma, rhinitis, conjunctivitis, allergic alveolitis, organic dust toxic syndrome, chronic bronchitis, and airways obstruction. ${ }^{1}$ These conditions apply particularly to dairy farming. ${ }^{2}$

The Doubs region is a damp, semi-moun- tainous, fodder producing agricultural area of France where acute and chronic respiratory problems are common in dairy farmers. ${ }^{34}$ Occupational exposure in dairy farmers in the Doubs region principally comprises hay and microorganisms, since the use of toxic chemicals, ensilage, or feed additives is severely restricted.

A previous study carried out in the region showed that there were fewer microorganisms, especially thermophilic actinomycetes, on farms with an artificial barn drying system of fodder than on those using a traditional storage system. ${ }^{5}$ The aim of the present study was to determine whether barn drying of fodder is associated with lower levels of symptoms or less impairment of lung function in dairy farmers.

\section{Methods}

In a health programme organised by the local branch of the national health organisation for farmers, the Mutualité Sociale Agricole (MSA) of the Doubs, farmers receive a thorough medical examination every five years. This cross sectional study was carried out in cooperation with the MSA in five districts of the Doubs region. In 1990, 1857 active farmers of both sexes, working exclusively in dairying, agreed to participate in the study and were examined (response rate $81 \cdot 2 \%$ ). Two groups of farmers were studied within this cohort. Analysis of the two groups was by questionnaires (medical and occupational) and pulmonary function tests.

\section{STUDY POPULATION}

"Barn drying farmers" included all male farmers who had worked exclusively on dairy farms, were involved daily in cattle foddering, and had worked on farms which had had a barn drying system for at least three years. "Traditional storage farmers" comprised male farmers who had worked exclusively on dairy farms, were involved daily in cattle foddering, and had worked on farms using a traditional storage system and which were located in the same geographical area as the barn drying farms.

Selection of the two groups was as follows: at each MSA medical session, near the patient's home. At each of these medical sessions all male farmers were asked to answer a brief professional questionnaire (questions were asked by an MSA technician). At each session all those farmers who fulfilled the 
Table 1 Description of study population

\begin{tabular}{|c|c|c|c|}
\hline & $\begin{array}{l}\text { Barn drying } \\
\text { farmers } \\
(n=123)\end{array}$ & $\begin{array}{l}\text { Traditional } \\
\text { storage farmers } \\
(n=274)\end{array}$ & $p^{*}$ \\
\hline $\begin{array}{l}\text { Mean }(\mathrm{SD}) \text { age (years) } \\
<35 \text { years } \\
36-50 \text { years } \\
>50 \text { years }\end{array}$ & $\begin{array}{l}44 \cdot 4(10 \cdot 5) \\
25(20 \cdot 3 \%) \\
64(52 \cdot 1 \%) \\
34(27 \cdot 6 \%)\end{array}$ & $\begin{array}{l}43 \cdot 9(12 \cdot 2) \\
85(31 \cdot 0 \%) \\
91(33 \cdot 2 \%) \\
98(35 \cdot 7 \%)\end{array}$ & $\begin{array}{l}\text { NS } \\
<0.01\end{array}$ \\
\hline Mean (SD) height $(\mathrm{cm})$ & $173.4(5 \cdot 79)$ & $173.6(5.81)$ & NS \\
\hline Mean (SD) weight $(\mathrm{kg})$ & $74 \cdot 5(10 \cdot 6)$ & $74.9(12.5)$ & NS \\
\hline $\begin{array}{l}\text { Smoking habits } \\
\text { Non-smokers } \\
\text { Ex-smokers } \\
\text { Smokers } \\
\text { Mean (SD) pack years }\end{array}$ & $\begin{array}{l}73(59 \cdot 4 \%) \\
31(25 \cdot 2 \%) \\
19(15 \cdot 4 \%) \\
14 \cdot 4(9 \cdot 8)\end{array}$ & $\begin{array}{c}156(56.9 \%) \\
67(24.5 \%) \\
51(18.6 \%) \\
15.4(12.9)\end{array}$ & $\begin{array}{l}\text { NS } \\
\text { NS }\end{array}$ \\
\hline $\begin{array}{l}\text { Alcohol consumption } \\
\text { (g pure alcohol/day) } \\
\text { None }(<10) \\
\text { Mild }(10-50) \\
\text { Heavy }(>50)\end{array}$ & $\begin{array}{l}51(41 \cdot 5 \%) \\
51(41 \cdot 5 \%) \\
21(17 \%)\end{array}$ & $\begin{array}{r}107(39 \cdot 1 \%) \\
121(44 \cdot 2 \%) \\
46(16 \cdot 7 \%)\end{array}$ & NS \\
\hline
\end{tabular}

* $\chi^{2}$ test; Student's $t$ test.

above criteria of "barn drying farmers" (from one to three at each session) and the first five male farmers who fulfilled the above criteria of "traditional storage farmers" were included in the study. These subjects were then invited to answer a medical and occupational questionnaire put by blind investigators and to undergo spirometric tests.

\section{Questionnaires}

The questionnaire included personal and demographic information, smoking habits, alcohol consumption, past respiratory history, chronic and acute symptoms (and their relations to exposure), and occupational information. Questions on respiratory symptoms were adapted from the questionnaire of the American Thoracic Society. ${ }^{6}$ Occupational questions designed to estimate exposure were drawn up by the authors working jointly with engineers and technicians of the "Direction Départementale de l'Agriculture" of the Doubs. Chronic bronchitis was defined as cough and chronic expectoration for three months of the year or more for at least two consecutive years. Dyspnoea was defined as shortness of breath when hurrying on the level or walking up a slight hill.

Non-smokers were defined as those who had smoked an average of less than one cigarette, one cigar, or one pipe a day for a year. Smokers had smoked this amount or more; ex-smokers had stopped smoking at least one month before the time at which they filled out the questionnaire.

Exposure to fodder was estimated on the basis of the length of exposure, size of the cattle herd, and bale years (number of average density bales of hay or the equivalent when farmers used other methods of storage of hay fed to cattle per day, multiplied by the number of years of foddering).

Table 2 Comparison of estimated exposure in the two groups

\begin{tabular}{lccl}
\hline & $\begin{array}{l}\text { Barn drying } \\
\text { farmers } \\
(n=123)\end{array}$ & $\begin{array}{l}\text { Traditional } \\
\text { storage farmers } \\
(n=274)\end{array}$ & $p^{*}$ \\
\hline Mean (SD) length of exposure (years) & $17(5 \cdot 1)$ & $17 \cdot 1(6 \cdot 8)$ & NS \\
Mean (SD) number of cattle & $88 \cdot 1(35 \cdot 8)$ & $67 \cdot 3(28 \cdot 5)$ & $<0.001$ \\
Mean (SD) bale years & $975(577)$ & $752(549)$ & $<0.001$ \\
\hline
\end{tabular}

* Student's $t$ test.
Respiratory function tests

A portable pneumotachograph (Autospiro Minato AS 500, Medical Science Company Ltd, Osaka, Japan) was used to measure slow vital capacity (VC), forced expiratory volume in one second $\left(\mathrm{FEV}_{1}\right)$, and forced mid expiratory flow $\left(\mathrm{FEF}_{25-75}\right)$. A minimum of three adequate measurements was obtained in each subject. The best values were selected after correction to BTPS. All measurements were made by the same trained technician. Values obtained were expressed as a percentage of the theoretical values of the European Coal and Steel Community calculated in relation to sex, age, and height.

\section{DATA ANALYSIS}

Respiratory symptoms and function were compared in the two groups with the $\chi^{2}$ and Student's $t$ tests. Logistic regression and analysis of variance were used for adjustments for confounding individual and occupational factors. A BMDP statistical software package was used; $p$ values of $\leqslant 0.05$ were regarded as significant; $p$ values of $<0 \cdot 1$ are reported in the tables.

\section{Results}

Data were collected from 123 farmers who met the criteria for inclusion in the barn drying group, and 274 who used traditional methods. The two groups of farmers were comparable for mean age, height and weight, smoking habits, and alcohol consumption (table 1). There was, however, a greater percentage of middle aged farmers (36-50 years) in the barn drying group. Exposure, estimated on the basis of the size of the cattle herd and of the quantity of fodder handled during the working life of the farmers, was greater in the barn drying group (table 2), but length of exposure was the same in both groups.

The incidence of past respiratory problems was the same in the two groups; four $(3.2 \%)$ farmers in the barn drying group and six $(2 \cdot 2 \%)$ in the traditional storage group had had previous acute episodes suggestive of farmer's lung. Chronic symptoms and acute current symptoms related to exposure were all less frequent in farmers exposed to barn dried fodder than in other farmers, but the differences were not significant (table 3 ). The greatest differences concerned symptoms of asthma (shortness of breath with wheeze) $(3.3 \% v 6.2 \%)$ and semi-delayed respiratory symptoms $(1.6 \%$ v $5.5 \%)$.

All measures of respiratory function, particularly the expiratory flow parameters, were significantly better in the group exposed to barn dried fodder than in the other farmers (table 4). There was also a positive correlation between chronic symptoms (but not acute exposure related symptoms) and age, smoking habits, and exposure (length of exposure and bale years). There was no relation between respiratory function parameters and exposure. Expiratory flow parameters were negatively correlated with smoking habits. 
Table 3 Comparison of the frequency of symptoms in the two groups

\begin{tabular}{|c|c|c|c|}
\hline & $\begin{array}{l}\text { Barn drying } \\
\text { farmers } \\
(n=123)\end{array}$ & $\begin{array}{l}\text { Traditional } \\
\text { storage farmers } \\
(n=274)\end{array}$ & $p^{*}$ \\
\hline $\begin{array}{l}\text { Past history } \\
\text { Allergies } \\
\text { Any respiratory disease(s) }\end{array}$ & $\begin{array}{c}8(6 \cdot 5 \%) \\
15(12 \cdot 2 \%)\end{array}$ & $\begin{array}{l}19(6.9 \%) \\
33(12.0 \%)\end{array}$ & $\begin{array}{l}\text { NS } \\
\text { NS }\end{array}$ \\
\hline $\begin{array}{l}\text { Respiratory symptoms } \\
\text { Chronic bronchitis } \\
\text { Dyspnoea } \\
\text { Asthma (diagnosed by doctor) }\end{array}$ & $\begin{array}{c}18(14 \cdot 6 \%) \\
14(11 \cdot 4 \%) \\
6(4 \cdot 9 \%)\end{array}$ & $\begin{array}{l}45(16 \cdot 4 \%) \\
36(13 \cdot 1 \%) \\
14(5 \cdot 1 \%)\end{array}$ & $\begin{array}{l}\text { NS } \\
\text { NS }\end{array}$ \\
\hline $\begin{array}{l}\text { Current symptoms related to } \\
\text { exposure** } \\
\text { Eye irritation } \\
\text { Nose irritation } \\
\text { Cough } \\
\text { Shortness of breath with } \\
\text { wheeze }\end{array}$ & $\begin{array}{c}3(2 \cdot 4 \%) \\
28(22 \cdot 7 \%) \\
13(10 \cdot 6 \%) \\
4(3 \cdot 3 \%)\end{array}$ & $\begin{array}{l}9(3 \cdot 3 \%) \\
77(28 \cdot 1 \%) \\
35(12 \cdot 8 \%) \\
17(6 \cdot 2 \%)\end{array}$ & $\begin{array}{l}\text { NS } \\
\text { NS } \\
\text { NS } \\
\text { NS }\end{array}$ \\
\hline $\begin{array}{l}\text { SDRS } \\
\text { One or more of the above } \\
\text { symptoms }\end{array}$ & $\begin{array}{c}2(1.6 \%) \\
35(28 \cdot 4 \%)\end{array}$ & $\begin{array}{l}15(5.5 \%) \\
98(35.8 \%)\end{array}$ & $\begin{array}{l}<0.1 \\
<0.1\end{array}$ \\
\hline
\end{tabular}

SDRS = semi-delayed respiratory symptoms: cough and dyspnoea with fever (or sensation of) occurring 4-10 hours after exposure to mouldy fodder.

* $p$ value after adjustments for age, exposure, and smoking (logistic regression)

** Having (re)occurred within the last year.

\section{Discussion}

This study has shown that farmers working on a modern farm with artificial barn drying of fodder have better respiratory function than those using traditional methods of fodder storage. Although no significant difference was found between the two groups regarding exposure related acute or chronic respiratory symptoms, the prevalence of all respiratory symptoms was lower in the group working with barn dried fodder. This suggests that barn drying of fodder results in lower symptom levels and better lung function.

This was a cross sectional study and must be interpreted cautiously, so the results merit confirmation by long term follow up of the two groups. Barn drying was not the only difference between the groups, since farms in which barn drying is used are more likely to have had other modern facilities installed such as a cowshed ventilation system, a central feeding corridor in the cowshed, and location of the barn at a distance from the cowshed (not above as is the tradition in the Doubs) than farms with a traditional storage system. A selection bias also cannot be excluded: the modernisation of farming activities, including the installation of barn drying facilities, is costly and it is possible that farmers with health problems (including respiratory) might not be particularly tempted to undertake the work necessary to bring their farms up to date.

The two groups compared here were similarly distributed for sex, mean age, smoking habits and alcohol consumption, which are factors of significance in chronic obstructive lung disease. A fifth potentially important fac-

Table 4 Comparison of respiratory function parameters in the two groups

\begin{tabular}{lllll}
\hline & $\begin{array}{l}\text { Barn drying } \\
\text { farmers } \\
(n=123)\end{array}$ & $\begin{array}{l}\text { Traditional } \\
\text { storage farmers } \\
(n=274)\end{array}$ & $p 1$ & $p 2$ \\
\hline Interpretable data & $122(99 \cdot 2 \%)$ & $267(97.4 \%)$ & & \\
VC & $104(13.9)$ & $101.6(15.5)$ & 0.05 & NS \\
FEV $_{1}$ & $99.3(14 \cdot 1)$ & $94.4(17.8)$ & $<0.01$ & $<0.05$ \\
FEV $_{1} /$ VC & $96.3(11)$ & $92.4(16.2)$ & $<0.01$ & $<0.05$ \\
FEF $_{25-75}$ & $87.4(23.6)$ & $79(25.6)$ & $<0.001$ & $<0.005$ \\
\hline
\end{tabular}

$\mathrm{VC}=$ vital capacity; $\mathrm{FEV}_{1}=$ forced expiratory volume in one second; $\mathrm{FEF}_{25-75}=$ forced mid expiratory flow.

Results are expressed as mean (SD) percentage of theoretical values (ECSC standards) calculated in relation to age, sex and height.

p1 = Student's $t$ test; $\mathbf{p}^{2}=$ analysis of variance with adjustments for age, exposure, and smoking. tor, alpha-1 antitrypsin level, was not evaluated. It was decided to include only obviously exposed workers (daily feeding of cattle) in the study for the protective effect of barn drying (if it exists) to emerge without having to use a large number of subjects. The same reasoning explained the inclusion only of subjects in the barn drying group who had used the technique for at least three years.

These results are in agreement with the microbiological study recently undertaken in the same region. ${ }^{5}$ We had found that exposure to fungal and bacterial microorganisms (thermophilic actinomycetes) was lower in modern farms than in traditional farms and, in particular, that barn drying reduced air contamination with thermophilic actinomycetes. The effects of the artificial drying of fodder on air contamination with microorganisms has been discussed elsewhere ${ }^{5}$ and will not be discussed again here. It is reasonable to extrapolate the results of that microbiological study to the present study since farms were located in the same region and were involved in the same agricultural processes (milk and beef). The protective effect against air contamination with thermophilic actinomycetes, which was particularly significant, probably explains the difference between the two groups for semidelayed respiratory symptoms which were compatible with an organic dust toxic syndrome and also with farmer's lung $(1.6 \%$ in the barn drying group $v 5.5 \%$ in the control group).

The clearest results, however, were in respiratory function, particularly flow rate, which was better in the barn drying group. Several studies have suggested that dairy farmers are exposed to a greater risk of chronic bronchitis, chronic obstructive airway disease, or both. ${ }^{4-10}$ It is not known in the context of fodder related activities, however, if this bronchial involvement is directly related to the level of exposure to organic particles, particularly fungal or bacterial microorganisms. In contrast, in grain farming it is suggested that bronchial obstruction is directly linked to levels of vegetable dust, ${ }^{11}$ possibly with a dose-effect relation. ${ }^{1213}$ Epidemiological studies in other agricultural contexts have linked bronchial disease to the presence or level of endotoxins. ${ }^{14-16}$ The proinflammatory properties of endotoxins are well known but it is also possible that high levels of moulds and actinomycetes could be responsible for chronic bronchial inflammation ${ }^{17}$ which might play an important part in the development of chronic obstructive airway disease.

It is thus possible that reduced air contamination by microorganisms resulting from artificial drying of fodder could be responsible for the beneficial results seen in this study. A study of the relation between levels of microorganisms and respiratory function in dairy farmers is needed to confirm this, as has been the case with grain silo workers. Longitudinal clinical and respiratory function monitoring of our two study groups will be used to attempt to confirm the hypothesis of the protective effect of barn drying. 
1 Merchant JA. Agricultural exposures to organic dusts. Occup Med 1987;2:409-25.

2 Malmberg P. Health effects of organic dust exposure in dairy farmers. Am $\mathcal{F}$ Ind Med 1990;17:7-15.

3 Depierre A, Dalphin JC, Pernet D, Dubiez A, Faucompre C, Breton JL. Epidemiological study of farmer's lung disease in five districts of the French Doubs province. Thorax 1988;43:429-35.

4 Dalphin JC, Bildstein F, Pernet D, Dubiez A, Depierre A. Prevalence of chronic bronchitis and respiratory function in a group of dairy farmers in the French Doubs province. Chest 1989;95:1244-7.

5 Dalphin JC, Pernet D, Reboux G, Martinez J, Dubiez A, Barale Th, et al. Influence of mode of storage and drying of fodder on thermophilic actinomycete aerocontamination in dairy farms of the Doubs region of France. Thorax 1991;46:619-23.

6 Ferris BG. Epidemiology standardization project. Am Rev Respir Dis 1978;118 (Suppl 6, part 2): 1-88.

7 Husman K, Koskenvuo M, Kaprio J, Terho EO, Vohlonen I. Role of environment in the development of chronic bronchitis. Eur F Respir Dis 1987;71(Suppl 152):57-63.

8 Saia B, Mastrangelo G, Marcer G, Reggio O. Prevalence and risk factors of chronic respiratory disease in a farming population. Med Lav 1984;75:101-9.

9 Dosman JA, Graham BL, Hall D, Van Loon P, Bhasin P, Froh $\mathrm{F}$. Respiratory symptoms and pulmonary function in farmers. $\mathcal{f}$ Occup Med 1987;29:38-43.
10 Heller RF, Hayward DM, Farebrother MTB. Lung function of farmers in England and Wales. Thorax tion of farme

11 WHO Study Group. Recommended health-based occupational exposure limits for selected vegetable dusts. Geneva: WHO Technical Report Series 684, 1983.

12 Enarson DA, Vedal S, Chan-Yeung M. Rapid decline in FEV $_{\text {in }}$ grainhandlers: relation to level of dust exposure. Am Rev Respir Dis 1985;132:814-7.

13 Huy T, de Schiffer K, Chan-Yeung M, Kennedy S. Grain dust and lung function: dose-response relationships. $A m$ Rev Respir Dis 1991;144:1314-21.

14 Donham KJ, Haglind P, Peterson Y, Rylander R, Belin L. Environmental and health studies of farm workers in Swedish swine confinement buildings. $\mathrm{Br} \mathcal{F}$ Ind Med 1989;46:31-7.

15 Heederick D, Brouwer R, Biersteker K, Boleij JSM. Relationship of airborne endotoxin and bacteria levels in pig farms with the lung function and respiratory symptoms of farms with the lung function and respiratory symptoms of

16 Kennedy SM, Christiani DC, Eisen EA, Wegman DH, Greaves IA, Olenchock SA, et al. Cotton dust and endotoxin exposure-response relationships in cotton textile workers. Am Rev Respir Dis 1987;135:194-200.

17 Malmberg P, Rask-Andersen A. Natural and adaptive immune reactions to inhaled microorganisms in the lung of farmers. Scand f Work Environ Health 1988;14 (Suppl 1):68-71. 